\title{
Perception of Nursing Work Satisfaction in Patient Safety Culture
}

\author{
Titi Purwani ${ }^{1}$, Fahmi Rahmy ${ }^{2}$, Zifriyanthi Minanda Putri ${ }^{3}$ \\ 1,2,3 University of Andalas, Padang, Indonesia \\ Email: titipurwani2@gmail.com
}

\begin{abstract}
Health service mistakes can result in thousands of people dying annually. One strategy to improve patient safety is to create the safety culture of patients with the satisfaction of nursing work. The dissatisfaction of nurses work can lead to a decline in hospital service quality. Objective: This study aims to know the relationship perception of nurse work satisfaction to patient safety culture. The studies used are descriptive-analytic with a crosssectional approach. The sample number of 137 nurses taken at Padang in the 2020 period with total sampling techniques. There is a significant link between salary satisfaction, supervision, additional benefits, motivation, technical procedures, communication, and nursing work satisfaction with the safety culture of the patient. The most significant relationship is supervision with the safety culture of the patient.
\end{abstract}

Keywords: Job Satisfaction, Nursing, Patient Safety Culture.

\section{A. INTRODUCTION}

About 98,000 people die every year in the United States due to health service errors [1]. The death amount will be the same as the three planes crashing every day. One strategy to determine and improve patient safety in health institutions is to create a patient safety culture [2]. The safety culture of an organization is the values, attitudes, perception, competence, and behavior patterns of individuals and groups that determine the commitment, health, and safety management of the Organization. Patient safety culture emphasizes patient safety and incident reporting [3].

Cairo Egypt's educational hospital reports that the most dominant dimension to the increase in patient safety culture is the continuous improvement of organization/improvements as much as $78,2 \%$ [4]. While study in Belgium, communication dimension and shift turnover is a major problem in the safety culture of the patient, there is a gap difference in the perception of safety culture between staff and management [5]. In addition at the University Hospital Hasanudin the highest dimension is cooperation in units of $95.10 \%$, while the dimensions of the perception response about the safety of patients classified as $51.47 \%$ [6]. While the results of study in RS Panti Rapih Yogyakarta in 2012, the dimension of sustainable learning development $81.67 \%$, the working dimension of the team in the unit $79.30 \%$, dimension of management support to the safety of patients $75.68 \%$ and dimensions of cooperation between units $72.30 \%$ [7].

Employees who provide high loyalty services to the organization are affected by the perception of employees on their work, colleagues, and superiors. Employees who feel satisfaction in working will usually work harder and better than frustrated 
employees [8]. Meanwhile, employees who feel dissatisfaction in working tend to behave negatively such as demonstration action, strike, and backing work, and so on [9]. Study conducted at Hospital Rasht City reports that there is a relationship between nursing work satisfaction and patient safety culture with a significant correlation coefficient between 0.643 to 0.01 [10]. An adequate atmosphere can enhance the work satisfaction, performance, and safety of patients [11]. The 2019 Quality Indicators report in Padang Hospital that employee satisfaction of $55 \%$ is related to the dimensions of working procedures and regulations, supervision, awards, salary, additional allowances and promotions [12]. In 2018 the data on patient safety incident obtained data 0 (no incident), while the year 2019 obtained the incidence of phlebitis (inflammation of blood vessels due to infusion), there has been no reporting of potential incidents or injury risks. Besides, there is a nurse who resigned from her job more or less 10 per year. However it is not yet known whether the perception of nursing work satisfaction (on salary, promotion, supervise, general benefits, moral rewards, technical procedures, partners, atmosphere, communication) is associated with patient safety culture.

\section{B. METHODS}

The type of study used is descriptive-analytic with cross-sectional approaches. Analysis of the data used is the Chi-square test by testing the relationship between variables. Independent variables on this study are factors that affect the job satisfaction of nurses covering Salary, promotion, supervision, additional benefits, motivation, technical procedures, partners, working atmosphere, and communication. The dependent variables in this study are the safety culture of the patient. The sample is of 130 nurses taken in a total sampling way. Data is taken from April to May 2, 2020, with an online questionnaire spread.

\section{RESULTS}

The safety culture of patients overall according to the perception of most nurses $(61.5 \%)$ in the category of strong safety culture, while the perception of nurses who expressed a strong/reliable safety culture as much as 38.5\% and no nurses are declaring weak safety cultures.

Table 1 Frequency Distribution Patient Safety Culture

\begin{tabular}{lcc}
\hline Safety Culture Patient & $\mathrm{f}$ & $\%$ \\
\hline Strong/Reliable Safety culture & 50 & 38.5 \\
Safety culture is strong enough & 80 & 61,5 \\
Weak safety culture & 0 & 0 \\
\hline Total & $\mathbf{1 3 0}$ & $\mathbf{1 0 0 . 0}$ \\
\hline
\end{tabular}


Table 2 Frequency Distribution Perceptions Nurse Job Satisfaction

\begin{tabular}{lcc}
\hline Job Satisfaction & $\mathrm{f}$ & $\%$ \\
\hline Satisfied & 48 & 37 \\
Dissatisfied & 82 & 63 \\
\hline Total & 130 & 100.0 \\
\hline
\end{tabular}

Based on table 2 known that from 130 nurses in Padang Hospital perception of most work satisfaction (63\%) Nurse in the satisfied category and (37\%) In the category are dissatisfied.

Highest satisfaction dimensions on partner dimensions and working atmosphere dimensions (95.4\%), but from the additional benefits, the respondent's satisfaction is only (37.7\%). It means most respondents (62.3\%) expressed dissatisfaction with the dimension of additional benefits (table 3).

\begin{tabular}{|c|c|c|}
\hline Perceptions Nurse Job Satisfaction & $\mathrm{f}$ & $\%$ \\
\hline $\begin{array}{l}\text { Salary Satisfaction } \\
\text { Satisfied } \\
\text { Dissatisfied }\end{array}$ & $\begin{array}{l}60 \\
70\end{array}$ & $\begin{array}{l}46,2 \\
53.8\end{array}$ \\
\hline $\begin{array}{l}\text { Development opportunities } \\
\text { Satisfied } \\
\text { Dissatisfied }\end{array}$ & $\begin{array}{l}47 \\
83\end{array}$ & $\begin{array}{l}36,2 \\
63,8\end{array}$ \\
\hline $\begin{array}{l}\text { Supervision } \\
\text { Satisfied } \\
\text { Dissatisfied }\end{array}$ & $\begin{array}{c}24 \\
106\end{array}$ & $\begin{array}{l}18,5 \\
81,5\end{array}$ \\
\hline $\begin{array}{l}\text { Additional Benefits } \\
\text { Satisfied } \\
\text { Dissatisfied }\end{array}$ & $\begin{array}{l}81 \\
49\end{array}$ & $\begin{array}{l}62,3 \\
37,7\end{array}$ \\
\hline $\begin{array}{l}\text { Motivation } \\
\text { Satisfied } \\
\text { Dissatisfied }\end{array}$ & $\begin{array}{c}27 \\
103\end{array}$ & $\begin{array}{l}20,8 \\
79,2\end{array}$ \\
\hline $\begin{array}{l}\text { Technical Procedures } \\
\text { Satisfied } \\
\text { Dissatisfied }\end{array}$ & $\begin{array}{l}53 \\
77\end{array}$ & $\begin{array}{l}40,8 \\
59,2\end{array}$ \\
\hline $\begin{array}{l}\text { Partners } \\
\text { Satisfied } \\
\text { Dissatisfied }\end{array}$ & $\begin{array}{c}6 \\
124\end{array}$ & $\begin{array}{c}4,6 \\
95,4\end{array}$ \\
\hline $\begin{array}{l}\text { Working Atmosphere } \\
\text { Satisfied } \\
\text { Dissatisfied }\end{array}$ & $\begin{array}{c}6 \\
124\end{array}$ & $\begin{array}{c}4,6 \\
95,4\end{array}$ \\
\hline $\begin{array}{l}\text { Communication } \\
\text { Satisfied } \\
\text { Dissatisfied }\end{array}$ & $\begin{array}{c}17 \\
113\end{array}$ & $\begin{array}{l}13,1 \\
86,9\end{array}$ \\
\hline
\end{tabular}


The results of the analysis of the relationship between nurse perception of job satisfaction with cultural patient safety are as follows:

Tabel 4 Relationship Perceptions Nurse Job Satisfaction with Safety Culture Patient

\begin{tabular}{|c|c|c|c|c|}
\hline \multirow{3}{*}{$\begin{array}{c}\text { Variable } \\
\text { Perceptions Nurse } \\
\text { Job Satisfaction }\end{array}$} & \multicolumn{4}{|c|}{ Safety Culture Patient } \\
\hline & $\begin{array}{l}\text { Strong/Reliable } \\
\text { Safety culture }\end{array}$ & $\begin{array}{l}\text { Safety culture } \\
\text { is strong } \\
\text { enough }\end{array}$ & OR & P value \\
\hline & $\mathrm{F}(\%)$ & $\mathrm{F}(\%)$ & & \\
\hline Salary Satisfaction & & & 0,443 & 0,044 \\
\hline Satisfied & $17(28,3)$ & $43(71,7)$ & & \\
\hline Dissatisfied & $33(47,1)$ & $37(52,9)$ & & \\
\hline Development & & & 0,554 & 0,18 \\
\hline opportunities & $14(29,8)$ & $33(70,2)$ & & \\
\hline Satisfied & $36(43,4)$ & $47(56,6)$ & & \\
\hline Dissatisfied & & & & \\
\hline Supervision & & & 0,051 & 0,00 \\
\hline Satisfied & $1(4,2)$ & $23(95,8)$ & & \\
\hline Dissatisfied & $49(46,2)$ & $57(53,8)$ & & \\
\hline Additional Benefits & & & 0,492 & 0,08 \\
\hline Satisfied & $26(32,1)$ & $55(67,9)$ & & \\
\hline Dissatisfied & $24(49,0)$ & $25(51,0)$ & & \\
\hline Motivation & & & 0,216 & 0,009 \\
\hline Satisfied & $4(14,8)$ & $23(85,2)$ & & \\
\hline Dissatisfied & $46(44,7)$ & $57(55,3)$ & & \\
\hline Technical Procedures & & & 0,351 & 0,012 \\
\hline Satisfied & $13(24,5)$ & $40(75,5)$ & & \\
\hline Dissatisfied & $37(48,1)$ & $40(51,9)$ & & \\
\hline Partners & & & 0,792 & 1,00 \\
\hline Satisfied & $2(33,3)$ & $4(100)$ & & \\
\hline Dissatisfied & $48(38,7)$ & $76(60,3)$ & & \\
\hline Working & & & 0,792 & 1,00 \\
\hline Atmosphere & $2(33,3)$ & $4(100)$ & & \\
\hline Satisfied & $48(38,7)$ & $76(61,3)$ & & \\
\hline Dissatisfied & & & & \\
\hline Communication & & & 0,181 & 0,03 \\
\hline Satisfied & $2(11,8)$ & $15(88,2)$ & & \\
\hline Dissatisfied & $48(42,5)$ & $65(57,5)$ & & \\
\hline Nursing Work & & & 4,235 & 0,049 \\
\hline Satisfaction & $2(14,3)$ & $12(85,7)$ & & \\
\hline Satisfied & $48(41,4)$ & $68(58,6)$ & & \\
\hline Dissatisfied & & & & \\
\hline
\end{tabular}


The nurse who is satisfied with her salary has a strong/reliable patient safety culture (47.1\%). P-value 0.044 means a significant relationship between the satisfaction of the nurse's salary with the safety culture of the patient and the OR (Odd Ratio) of 0.443. It means the nurse who satisfied with her salary 443 per mile more likely to have a strong safety culture/reliability. Respondents who are satisfied with the development opportunities have a safety culture that is quite as much as $56.6 \%$ with P-value 0.18. It means that there is no significant relationship between the satisfaction of the development of nurse opportunities with the safety culture of the patient. Nurses who are satisfied with supervision have a safety culture that is quite as much as $52.9 \%$ with a value of P-value 0.00 Its means that there is a significant relationship between the satisfaction of nurse supervision with patient safety culture. While OR 0.051 means nurses who are satisfied with supervision are 51 per mile more likely have a strong safety culture/reliability.

Employees who are satisfied with the added benefits of having a sufficient safety culture is $51 \%$ and P-value 0.08 . It means that there is no significant link between the satisfaction of the additional benefits of nurses with the safety culture of the patient. Nurses who are satisfied with the motivation have a safety culture that is enough 55.3\% with P-value 0.009. It means that there is a significant link between the satisfaction of a nurse's motivation with the safety culture of patients. As for the Odds Ratio of 0.216 , it means nurses who are satisfied with the motivation 216 per mile more likely to have a strong safety culture/reliability. Respondents who are satisfied with the technical procedures have a sufficient safety culture $51.9 \%$ with Pvalue 0.012 . It means that there is a significant relationship between the satisfaction of the technical procedures of nurses with patient safety culture. The value of the result OR 0.351, means the nurse who satisfied with the technical procedure 351 per mile more likely has a strong safety culture/reliability.

Respondents who are satisfied with nurse partners have adequate safety culture $(60.3 \%)$. Test results statistic obtained the value of P-value 1.00, it means that there is no significant relationship between the satisfaction of nurse partners with the culture of patient safety. Nurses who are satisfied with the working atmosphere have a safety culture that is quite as much as $61.3 \%$. The test result statistic obtained the value of P-value 1.00, that there is no significant relationship between the satisfaction of the nursing work atmosphere with the safety culture of the patient. Nurses who are satisfied with communication as much as $57.5 \%$ of nurses have adequate safety culture with a value of P-value 0.03 , it can be concluded that there is a significant relationship between the satisfaction of nursing communication with the culture of patient safety. While the value of OR 0.181, means a nurse who is satisfied with communication 181 per mile more likely to have a strong/reliable safety culture. Nurses who feel in job satisfaction in a satisfied category that has a safety culture of $58,6 \%$ with a value of $P$-value 0.049 , it can be concluded that there is a significant relationship between nursing work satisfaction with patient safety culture. OR 4.235, which means the nurse who is satisfied with the satisfaction of its work has 4.235 times the opportunity to have a strong/reliable safety culture. 


\section{DISCUSSION}

\section{Primary Patient Safety Culture}

Patient safety culture is the values of individuals and groups, attitudes, perception, competence and behavior patterns committed to supporting the management and Patient Safety Program [13]. The good safety culture indicator is if the safety culture is more than $75 \%$ demonstrates the safety culture of patients strong/reliable and needs to be maintained. Figures between 50-75\% show the safety culture of the patient is good enough, but still need better improvement efforts, while the number of the $<50$ means weak safety culture that requires improvement of the system [14]. Patient safety culture at Padang Hospital in the category is quite strong and reliable $(80 \%)$. The result of this study is higher compared with the results of the study of safety culture in the nurses in RS Roemani Semarang are categorized as moderate/strong enough with the percentage (71\%) [15]. According to the study it requires better improvement efforts without the need for improvement of the system.

\section{Perceptions Nurse Job Satisfaction}

From 130 nurses in Padang Hospital perception of most work satisfaction (63\%), Nurses in the category are satisfied, and 37\% are not satisfied. This study is slightly lower than the study results of the District General Hospital Banyuwangi Blambangan with the overall results of the employees provide a satisfaction rating of staff of $68.95 \%$. Job satisfaction is an individual thing. Each individual will have varying degrees of satisfaction according to the system of values that apply to him. When the organization pays attention to employee work satisfaction, employees will be increasingly working so that productivity and service are increasing[16]. The results of this study in accordance with the results of the study in Rasht City Hospital Iran that there is a significant direct connection between the satisfaction of nursing work and the culture of patient safety with a significant correlation coefficient between 0.643 to 0.01 with the conclusion of increased job satisfaction nurse resulted in an increase in patient safety culture [10]. The working satisfaction factor also has the opportunity to improve patient safety because it has a close correlation with the performance in the field of nursing Services [17]. The results of the study at the Minnesota Hospital found that there was a positive correlation between nursing work satisfaction and the quality of care [18]. In the Netherlands, dissatisfaction and intention to go lower than most countries, only $6 \%$ of nurses give their wards poor safety value or fail, and 35\% assess the treatment in their wards as fair or bad [19].

\section{Work Satisfaction Dimension}

The results of this study also showed that the highest working satisfaction level of the nurse Padang Hospital is on the "partner" factor of $83 \%$, or the average scorecard 4.98. As for the lowest working satisfaction factor is the additional benefit factor of $(37.7 \%)$ or averaging - the average of the 2.2 scores. This illustrates the 
teamwork of a very good nursing team in providing services, but there are variables that need to be improved, according to respondents are additional benefits variables. General benefits that are felt are recreational, sporting opportunities, outbound, and family gathering so as to improve the job satisfaction of the nurse will be able to improve the performance so that it can improve the Hospital service quality. The results of this study are in accordance with job satisfaction study conducted in Turkey by Skitsou (2015) with the highest satisfaction value in the statement of sympathy against the partner with a result of 4.71 or amounting (78\%) With the standard deviation (0.963), as well as the lowest satisfaction value in the statement of the additional benefit of 2.78 or as the amount $(46 \%)$ With the standard deviation 1.082 [20].

\section{Relationship Perceptions Nurse Job Satisfaction with Safety Culture Patient}

In study in India, it was found that staff with 25,000-34,000 salaries, experienced heavy stress. Salaries even in hospitals contributed to more pressure on working staff [21]. The results of the study in Minnesota also found that wages/compensation became the cause of the most significant factors affecting the quality of care delivery [18]. Among the reasons for the key implementation of safety, culture is that individual motivation is even rewarded, as it provides information needs related to patient safety, culturally related reports on human error, and nearly injured risk [22]. Satisfied employees will usually work harder and better than with frustrated employees [8]. Employees especially nursing staff should be satisfied with their work to be more productive in working so as to contribute greatly to the efficiency of hospitals [20]. Employee satisfaction will affect attitudes and behavior during work, especially will be reflected in the level of an occupational accident, attendance level, moral level, and labor turnover level [23]. The satisfaction of nurse on salary dimension $(53.8 \%)$, especially on the statement of salary/allowances/incentives too little and rarely $(37 \%)$, need as consideration for management because salary satisfaction affects work motivation and can affect the quality of nursing service so it can affect patient safety culture as well as pose risk to a patient safety incident.

The results of this study in accordance with the results of the study in Spain mentioned that the perception of job satisfaction nurses on promotion and development opportunities have an adequate perception, but there is no relationship with the perception of adequate cultural safety [24]. The results of the analysis on the opportunities of development/promotion of the lowest satisfaction is on the statement of a fair opportunity to be promoted for the outstanding nurse. In this case, even though an accomplished nurse does not have a fair chance to be promoted. But nurses continue to work in accordance with the standard operating procedures that apply, the satisfaction of nursing work on the development opportunity has no effect on attitudes, behaviors that make the program committed to the implementation of patient safety culture. 
This study result is similar to study in the city of Zabol, Iran, aspects of the supervision of actions that promote safety have significant results. As well as study results in Spain that the most related dimensions with high perceived safety (OR $\geq$ 10) are supervision on variable work satisfaction [10, 25]. in Mid Staffordshire Hospital, the British government commissioned reports from Robert Francis QC and Professor Don Berwick. Among their recommendations to improve the quality and safety of patient care is that supervision is in a very good position to support this activity. Supervision has patient safety and primary patient care quality, its shape may vary, although its function remains focused on patient safety, good quality clinical care, and professional welfare [26]. Satisfaction in supervision is very important because nursing supervision is a professional activity in nursing service that aims to improve the productivity of nursing work, effectiveness, and efficiency of nursing care services. Supervision is planning, directing, guiding, teaching, observing, encouraging, repairing, trusting, continuously evaluating each nurse patiently, fairly, and wisely so that supervision is an effective way to achieve organizational objectives.

The results of this study differ from the results of study in the hospital Athalassa Hospital Psychiatry Cyprus, the existence of "additional benefits" with the standard deviation of 1.082. [20]. Employee empowerment, management support, and reward systems are additional benefits as a majority factor that affects the safety culture of the patient among nurses working at Minia General Hospital [27]. In the provision of nursing care services based on nursing practice legislation committed to maintaining patient safety. Because nursing actions that are not in accordance with patient safety procedures can also be an act of practice mall which is an event that can invite the demands of patients as well as patient families. To carry out the commitment of patient safety culture is the main goal of nursing service although there are no additional benefits obtained by nurses. Although the satisfaction of additional benefits in Padang Hospital amounted to $(37.7 \%)$ But in order to maintain the safety of the patient Nurse Padang Hospital stated: "units in RS are working well to provide the best service for patients" (84\%). "Our units are actively conducting activities to improve the safety of socialization patients, exchanging information, discussion on patient safety $(83 \%)$.

The results of hospital study in Estonia show that the perception of job satisfaction is relevant to increased patient safety activities [28]. The results of the study implementation of patient safety culture in Tangerang district is known to have an influence between the motivation of nurses with the application of patient safety culture (patient safety culture) with a value of OR $=5.906$ (95\% CI $=2,044$ $17,063)$ which means low nurse motivation is likely five times greater for the implementation of patient safety culture in the less good category compared to highly motivated nurses. With high motivation, the attitude of nurses in supporting the implementation of the patient safety program will be higher also [29]. The results of this study are also in line Nurmalia \& Nivalinda stating that motivation relates to the application of Patient safety culture (p-value $=0.001)$ [30]. Motivation 
shows the extent to which an individual wants or is willing to strive to achieve good performance at work. The implementation of patient safety culture by nurses reflects the behavior of nurse performance and is influenced by nurse motivation. This demonstrates to build a strong safety culture needs to be supported by high motivation in patient safety performance as well as human resource management systems. As in this study, most respondents had a high level of motivation to provide service by implementing a patient safety culture[29]. Motivation is a characteristic of human psychology that contributes to the level of one's commitment. The motivation that nurses have is important because the high motivation can provide nursing care optimally in improving the quality, productivity of nursing services, minimizing the occurrence of mistakes so that the implementation of patient safety culture is a commitment to nursing services activities.

This study show that a reliable safety culture is only owned by $48.1 \%$ of respondents means there is still work dissatisfaction. In the technical procedure dimension related procedures that do not inhibit work, bureaucracy, or workflows that do not impede the work, additional workloads that cause execution of the work is not timely, as well as the volume of documents. This is a number of conditions that can affect job satisfaction [20]. The safety culture of individuals and groups will be committed to being personally responsible for their safety, acting to preserve, enhance, and communicate safety issues, trying to actively learn, adapt, and modify behaviors. However, when this commitment to safety is hampered by technical procedures, it will greatly affect the culture of safety. Based on the results of the analysis of the study required improvement of technical procedures, evaluation of operational procedures, bureaucracy/workflow, schedule and workload, document volume and so on, to improve the condition to better ensure safety.

Studies conducted work with partners/teamwork in nursing units better than in the entire unit. Teamwork is an interdependent component of performance that is required to effectively coordinate the performance of several team members.This study is in accordance with the results of study in hospitals in Iran that the results of the average positive response to the 12 aspects of patient safety are $62.9 \%$ with statistically significant variables in the Working Team dimension $(P=0.006)$ on patient safety culture. Nurses work equally well in units where they work but they make teamwork between units less in cooperation, indicating that there is a safety culture of each team independent of the other teami [1]. In this case, the satisfaction with the partner is $75 \%$ but has nothing to do with the safety culture of a reliable patient. The results of this study in the safety of the patient is not influenced by the satisfaction of work on the partners because each officer is competent and able to work in accordance with the Code of Ethics and the legislation of the invitation that applies so that the culture of safety is still implemented, it is also supported from the statement our unit actively conducts activities to improve patient safety; socialization, information exchange, discussion on patient safety $(83 \%)$, management policy hospital shows that patient safety is a top priority $(83 \%)$. 
This study differ slightly from the study conducted by the Roca-Castello et all stating that the atmosphere and the working environment, according to some studies that are consulted is fundamental to the safety of patients results also observed in this study, because the dimension "Working conditions" does not show a relationship with work satisfaction, but it shows the perception of safety [11]. While this is in accordance with the study results in China that respondents assessed the dimension of job satisfaction as the highest among all six-dimensional SAQ, followed by teamwork climate, working conditions, and stress recognition (the lowest) in Patient safety culture [31]. The results of this study by the results of the study in Kuningan District government hospital showed there is no significant influence on the condition/working atmosphere with the safety culture of patients with the value $p 0.507$ [32]. The results of this study show that nurses can work in any mood to keep the safety of patients following their professionalism based on their legal and ethical profession, to implement the safety culture of the patient.

This study is similar to the results of the study in Kuningan District government hospital showed a significant influence between management communication techniques ( $\mathrm{P}$ 0.0005, odds of 21.3) with the safety culture of the patient as an effort to create a culture of patient safety [32]. WHO reports the health personnel training in communication skills to encourage teamwork, successfully overcoming inter-personal conflicts, support the creation of an adequate work environment, and improve patient safety [33]. Work satisfaction in communication serves to control work behavior, motivate, explain what is done to improve work performance, as well as information needed in the decision-making team in the application of patient safety culture. The effect of good communication implementation can improve the relationship between leaders and members. Taking the time to build a relationship with staying committed to the quality of service, usually, this situation will be able to survive and produce a good marketing relationship especially in the application of patient safety culture [34]

\section{E. CONCLUSION}

There is a significant relationship between the safety culture of the patient with salary satisfaction (P-value 0.04$)$, supervision (P-value 0.00$)$, additional benefits (P-value 0.08), motivation (P-value 0.009), technical procedures (P-value 0.012), communication ( $\mathrm{P}$-value 0.03 ), and nursing work satisfaction ( $\mathrm{P}$-value 0049) and no relationship between patient safety culture with development opportunities (P-value 0.18), partners (P-value 1.00) and working atmosphere (P-value 1.00). The conclusion of this study is the work satisfaction Nurse Padang Hospital has a significant connection with the safety culture of patients with the most significant satisfaction variables is the variable of supervision.

\section{REFERENCES}

1. Güneş Ü. Y, Gürlek Ö, Sönmez M. A survey of the patient safety culture of hospital nurses in Turkey. Collegian. 2016;23(2):225-32. 
2. Ulrich B, Kear T. Patient Safety and Patient Safety Culture: Foundations of Excellent Health Care Delivery. Nephrol Nurs J. 2014;41(5):447-56.

3. Hickner J, Smith SA, Yount N, Sorra J. Differing perceptions of safety culture across job roles in the ambulatory setting: Analysis of the AHRQ Medical Office Survey on Patient Safety Culture. BMJ Qual Saf. 2016;25(8):588-94.

4. Abood SA, El-magd ANA. A Comparative Study on Factors Influencing Patient Safety Culture among Staff Nurses. 2018;7(3):1-8.

5. Vlayen A, Schrooten W, Wami W, Aerts M, Barrado LG, Claes N, et al. Variability of Patient Safety Culture in Belgian acute hospitals. J Patient Saf. 2015;11(2):110-21.

6. Bea IF, Pasinringi SA, Noor NB. Gambaran budaya keselamatan pasien di Rumah Sakit Universitas Hasanuddin Tahun 2013. 2013. p. 1-14.

7. PKPRS Panti rapih. Survey Budaya Keselamatan RS. Panti RAPIH 2010-2012: Evaluasi Keberhasilan Program Kerja Keselamatan Pasien dalam Membangun Budaya Keselamatan Pasien. 2012;1-79.

8. Lawter L, Kopelman RE, Prottas DJ. McGregor 's theory X / Y and job performance: A multilevel, multi-source analysis. J Manag Issues. 2015;XXVII(1):84-101.

9. Hakim L, Kusdiyanto. Analisis Pengaruh Budaya Organisasi terhadap Kinerja Karyawan (Studi Kasus PDAM Kota Surakarta). PublikasiilmiahUmsAcId. 2011;53-77.

10. OOksharaie $M$. The relationship between nurses' job satisfaction and patient safety culture in the hospitals of Rasht city. Faṣlnāmah-I Bihdāsht Va İminī-I Kār. 2016;6(3):91-102.

11. Roca-Castelló MR, Merino-Plaza MJ, Fikri-Benbrahim N, Morro-Martín MD, Carrera-Hueso FJ, Martínez-Asensi A. Relación entre la satisfacción laboral y la cultura de seguridad del paciente. Gac Sanit. 2017;32(4):352-61.

12. KMKP. Laporan Mutu Semen Padang Hospital. artikel. 2019;

13. Sorra J, Kabir K, Dyer N, Mardon R, Famolaro T. Exploring relationships between patient safety culture and patients' assessments of hospital care. Vol. 44, Journal of Nursing Administration. 2014. p. 131-9.

14. KARS. Nasional Akreditasi Rumah Sakit Edisi 1. 2018;

15. S Ultaria T dora, Arso SP, Sriatmi A. Gambaran budaya keselamatan pasien di rumah sakit roemani muhammadiyah Semarang. J Kesehat Masy. 2017;5:118-25.

16. Prayoga D, Lailiyah S, Dian J, Sari E. Analisis Kepuasan Karyawan Dan Akreditasi Rumah Sakit Umum Daerah Blambangan Kabupaten Banyuwangi. 2017;2(2):269-89.

17. Platis C, Reklitis P, Zimeras S. Relation between Job Satisfaction and Job Performance in Healthcare Services. Procedia - Soc Behav Sci. 2015;175:480-7.

18. Smith C. Cornerstone: A Collection of Scholarly and Creative Works for Minnesota State University, Mankato Developing a Commercial Product Using a Consumer Grade 3D Printer. 2019; 
19. Aiken LH, Sermeus W, Van Den Heede K, Sloane DM, Busse R, McKee M, et al. Patient safety, satisfaction, and quality of hospital care: Cross sectional surveys of nurses and patients in 12 countries in Europe and the United States. BMJ. 2012;344(7851):1-14.

20. Skitsou BA, MSc, PhD A, Anastasiou RGN, RMN, BSc, MSc M, Charalambous MD, MSc, PhD G, Andrioti BA, MSc, PhD D. Job Satisfaction of Nurses in a Psychiatric Hospital, in Cyprus. Vol. 8, International Journal of Caring Sciences. 2015. p. 683-97.

21. Badil, Ur-Rehman R. Association of Working Experience and Salary with Occupational Stress among Nurses. J Dow Univ Heal Sci. 2018;12(1):13-6.

22. Sammer CE, Lykens K, Singh KP, Mains DA, Lackan NA. What is patient safety culture? A review of the literature. J Nurs Scholarsh. 2010;42(2):156-65.

23. Josias BA. The relationship between job satisfaction and absenteeism in a selected field services section within an electricity utility in the Western Cape. 2005;(November):1-162.

24. Merino-Plaza MJ, Carrera-Hueso FJ, Roca-Castelló MR, Morro-Martín MD, Martínez-Asensi A, Fikri-Benbrahim N. Relationship between job satisfaction and patient safety culture. Gac Sanit. 2018;32(4):352-61.

25. Plaza M. Relationship Between Job Satisfaction and Patient Safety Culture. 2017;

26. Tomlinson J. Using clinical supervision to improve the quality and safety of patient care : a response to Berwick and Francis. Using Clin Superv to Improv Qual Saf patient care a response to Berwick Fr. 2015;1-8.

27. Laal F, Fazli B, Balarak D, Dalir F, Mohammadi M, Mirzaei R. Attitude toward the Patient Safety Culture in healthcare systems. Patient Saf Qual Improv. 2016;4(2):363-8.

28. Kristi Toode 1, Pirkko Routasalo, Mika Helminen TS. Hospital Nurses' Working Conditions in Relation to Motivation and Patient Safety. 2015;

29. Faridah I, Ispahani R, Badriah EL, Program D, Keperawatan S, Yatsi S, et al. Faktor-Faktor Yang Mempengaruhi Penerapan Budaya Keselamatan Pasien (Patient Safety Culture) Pada Perawat Di Rawat Inap Rsu Kabupaten Tangerang Keselamatan pasien atau patient safety merupakan sistem pelayanan rumah sakit yang pengobatan di rumah sakit. Keperawatan. 2019; VIII(1).

30. Nurmalia \& Nivalinda. Fungsi Manajemen Keperawatan Dalam Aplikasi Mentoring Budaya Keselamatan Pasien. Media Med Muda. 2016;2(2):99-104.

31. Jiang K, Tian L, Yan C, Li Y, Fang H, Peihang S, et al. A cross-sectional survey on patient safety culture in secondary hospitals of Northeast China. PLoS One. 2019;14(3):1-11.

32. Mulyati L. Fakor Determinan yang Memengaruhi Budaya Keselamatan Pasien di RS Pemerintah Kabupaten Kuningan Determinant factors that are Influencing Patient Safety Culture in a Government-owned Hospitals in Kuningan Regency. J Keperawatan Padjadjaran. 2016;4:179-90.

33. Coburn AF, Gage-croll Z. Improving Hospital Patient Safety Through Teamwork: The Use of TeamSTEPPS In Critical Access Hospitals. 2011; (June). 
34. Ismainar H, Dahesihdewi A, Dwiprahasto I. Efektivitas Kepemimpinan dan Komunikasi Tim Keselamatan Pasien di RSI Ibnu Sina Pekanbaru Riau. J Kesehat Komunitas. 2012;2(1):2-8. 